\title{
The impact of fire on timber supply in Ontario
}

\author{
David L. Martell
}

Results are presented for an assessment of the impact of fire on timber supply in the province of Ontario. Historical fire report data are used to develop statistical summaries of fire regimes in terms of annual fire occurrence and area burned by administrative district and region. A simple hypothetical jack pine forest is used to illustrate how forest level timber harvest scheduling models can be employed to assess the timber supply implications of fire management regimes. Although fire may have had a significant detrimental impact on timber supply in some parts of the Northwestern region during the 1976-88 period, the effectiveness of Ontario's forest fire management system is such that timber supply in most districts has not been significantly diminished by fire. The results of our timber supply analysis, and the fact that fire management also benefits public safety and reduces property loss, suggest forest fire management is profitable in Ontario.

Key words: forest fire impact, timber supply, mathematical programming, Ontario
Cet exposé présente les résultats de l'évaluation de l'impact des feux de forêt sur l'approvisionnement en matière ligneuse de la province de l'Ontario. Les données historiques des rapports sur les feux de forêt sont utilisées pour élaborer des sommaires statistiques sur les types de feux en terme d'occurrence annuelle et de superficies dévastées par district administratif et par région. Un peuplement ordinaire hypothétique de pin gris est utilisé pour démontrer comment les modèles de simulation de la récolte forestière en fonction de différentes époques permet d'évaluer les implications des types de gestion des feux de forêt sur l'approvisionnement en matière ligneuse. Même si les feux de forêt ont pu avoir un impact négatif déterminant sur l'approvisionnement en matière ligneuse dans certaines parties de la région du Nord-Ouest au cours de la période de 1976 à 1988 , l'efficacité du système de gestion des feux de forêt de l'Ontario est tel que l'approvisionnement en bois pour la pluparts des districts, n'a pas été affecté par le feu. Les résultats de nos analyses sur l'approvisionnement en bois, et le fait que la gestion des feux contribue également la sécurité du public et permet de minimiser les pertes de biens, laissent entendre que la gestion des feux de forêt est profitable en Ontario.

\section{Introduction}

Although fire is a natural component of many of Canada's forest ecosystems, it has both beneficial and detrimental impacts on forests and people who benefit from forests. Each year fire burns large portions of Canada's forested area, and fire management agencies spend significant amounts of money on efforts to limit its destructive impact. Fire managers and others find it difficult to assess the biological, economic, and social impact of fire, and they often resort to simple site specific evaluation procedures that yield little insight into the true impact of fire and fire management activities.

This paper reports the results of an assessment of the impact of fire on timber supply in the province of Ontario. The objectives were to produce a statistical summary of historical fire losses, to develop procedures useful in assessing the impact of fire on timber supply, and to use those procedures to obtain insight into the impact of fire on timber supply in Ontario. Initially, a statistical summary is presented based on 13 years of fire report data, of the simple physical impact of fire expressed in terms of annual fire occurrence and area burned by administrative district and region. Literature that pertains to the impact of fire on timber supply is reviewed and a description included, of how forest managers in Ontario deal with the impact of fire on timber supply when they develop their forest management plans. A slightly modified version of a mathematical programming model developed by Reed and Errico (1986) is used to evaluate timber management strategies and fire losses in a hypothetical flammable forest that is representative of parts of the boreal forest region of Ontario. The results of this evaluation are used to gauge the significance of the timber supply implications of Ontario's fire loss by district and region.

Faculty of Forestry, University of Toronto, 33 Willcocks Street, Toronto, Ontario, Canada M5S 3B3.
The paper concludes with a rough assessment of the value of Ontario's forest fire management program.

\section{Forest fire losses in Ontario}

The Ontario Ministry of Natural Resources (OMNR) is responsible for forest fire management on Crown lands in Ontario. Its fire management policy is based on an explicit recognition that fire is not always destructive and that it need not, and should not, be completely excluded from Ontario's forests. The OMNR's fire management program objectives are:

"to prevent personal injury, loss of life, and social disruption resulting from a forest fire, to minimize the negative impact of fire on public works, private property and the natural resources of Ontario, [and] to utilize the natural benefits of fire in achieving Ministry objectives for land and resource management" (Ontario Ministry of Natural Resources 1982).

Until recently ${ }^{1}$, the OMNR partitioned the province into 8 administrative regions, each of which was partitioned into several districts. Most of Ontario's forest fires occur in what is referred to as the Fire Region, a 781,346 square kilometre area to which the Forest Fires Prevention Act (the provincial government legislation which governs forest fire management in Ontario) applies. The Fire Region includes all or most of the Northwestern (NW), North Central (NC), Northern (NO), Northeastern (NE), and Algonquin (AL) regions, and smaller portions of the Eastern (EA), Central (CE), and Southwestern (SW) regions (Figure 1).

The OMNR uses a fire management zoning scheme that is

\footnotetext{
${ }^{1}$ On March 5, 1991, the OMNR announced a new field organization that consolidated 47 districts in 8 regions into 27 districts in 4 regions. The regions and districts referred to in this paper are those that existed prior to the 1991 re-organization.
} 


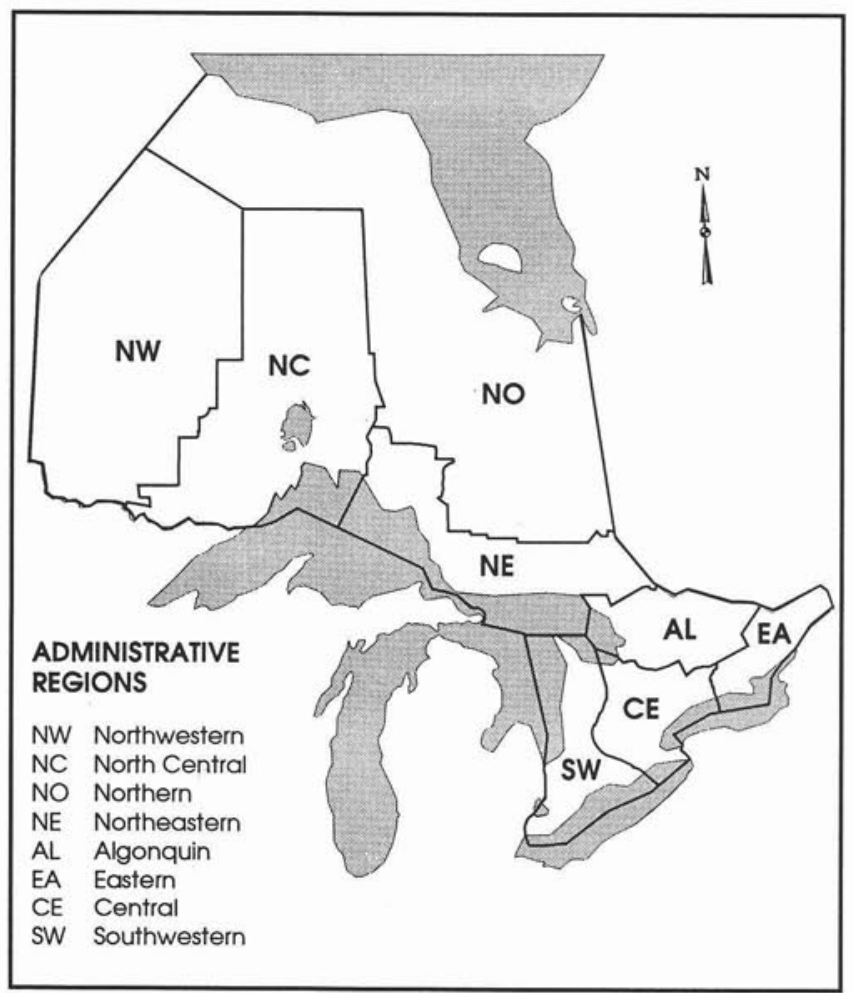

Figure 1. Forest administrative regions in Ontario.

designed to help ensure its fire suppression activities are consistent with its overall land management objectives. A fire management zone is a parcel or collection of parcels of land that are relatively homogeneous with respect to the potential impact of fire on people and land management objectives. Each administrative region is zoned such that fire management strategies and tactics are applied relatively uniformly within each zone, but differ from zone to zone.

Although the precise implementation of the zoning procedure varies from region to region, all land that is subject to forest fire management (i.e., the Fire Region) is zoned as either intensive, measured, or extensive protection for fire management purposes. The intensive protection zone encompasses land where fire has the potential to cause major social disruptions or can have a significant detrimental impact on natural resources. It includes land surrounding communities and land which contains resources that are currently being exploited or are scheduled to be developed in the immediate future. It covers 390,502 square kilometres, or $50 \%$ of the Fire Region. All fires in the intensive zone are aggressively attacked until they are suppressed.

The measured protection zone encompasses land where fire may cause significant damage to structures and recreational values but has limited potential to have a detrimental impact on natural resources. It includes land that contains isolated tourist camps and industrial facilities, and contingency timber that might be required to replace timber resources burned in the intensive protection zone. It covers 77,096 square kilometres or $10 \%$ of the fire region. ${ }^{2}$ All fires in the measured protection zone are attacked, but if they escape initial attack, they are subjected to an escaped fire situation analysis which might call for limited extended attack action rather than aggressive sustained attack.
The extensive protection zone encompasses land where fires may damage isolated localized values such as tourist facilities, trappers' cabins, and communications facilities, but have little detrimental impact on natural resources. It also envelops many small communities that are classified as part of the intensive protection zone. It covers 313,748 square kilometres or $40 \%$ of the fire region. Fires are monitored and suppression action is directed towards public safety ${ }^{3}$ and minimizing damage to localized values that are threatened.

Historical fire report data was used to compile a statistical summary of the extent of fire in Ontario during the years 1976 through 1988. An average of 1847 forest fires per year burned an annual average of 2,271 square kilometres of forest land in Ontario during that period. We used the 1987 version of the fire management zones the OMNR described on 1:600,000 Universal Transverse Mercator (UTM) Fire Management maps. The statistical analysis of the fire report data was simplified by approximating the zone boundaries by altering the boundaries used by the OMNR to conform with the boundaries of the closest $10 \mathrm{~km}$ by $10 \mathrm{~km}$ UTM basemaps. The UTM basemap number recorded on the fire report record was used to determine the zone within which each fire started.

The intensive and measured protection zone (i.e., the area that is heavily protected against fire) is 467,598 square kilometres in area. The average annual area burned in the intensive and measured protection zone is roughly 894 square kilometres or $0.19 \%$ of those zones, but that figure varies considerably from region to region.

The regional summary of the area burned during the 197688 fire seasons, (Table 1) indicates the size of each region's protection zones, the average number of fires per $1000 \mathrm{~km}^{2}$ per year in each zone, and the average and standard deviation of the fraction of each zone burned each year. The Central region is near the heavily populated southern portion of the province and experiences the highest fire occurrence in terms of average number of fires per $1000 \mathrm{~km}^{2}$. The Northwestern and North Central regions are much more heavily burned in terms of the fraction of the intensive protection zone burned each year. That discrepancy is a reflection of the fact that the Northwestern and North Central regions generally experience forest fuel and weather conditions that result in burning conditions that are more severe than those observed in other regions.

The intensive protection zone results (Table 2) suggest that most of the potential "problem areas" with respect to the fraction of the intensive protection zone burned, are located in the Northwestern and North Central regions. However, these burned area figures alone do not indicate the extent to which timber supply is adversely effected by fire. By moving beyond these simple statistics, an attempt is made to gauge potential fire problems in terms of their impact on timber supply. Investigations revealed that when the annual fraction burned each year is less

\footnotetext{
${ }^{2}$ This figure does not include the 19,283 square kilometre measured protection zone in the North Central region. The fire management strategy for much of the North Central region's measured protection zone is somewhat similar to the strategies that are applied to intensive protection land in the Northwestern and Northern regions. The North Central region's measured protection land was therefore classed as intensive protection land in our statistical summaries.

${ }^{3}$ Fires that threaten public safety are aggressively attacked regardless of their
} location. 
Table 1. Area burned in the intensive, measured, and extensive protection zones of Ontario's administrative regions, averaged during the 1976-88 fire seasons

\begin{tabular}{|c|c|c|c|c|c|}
\hline Region & Zone & $\begin{array}{c}\text { Zone size } \\
\left(\mathbf{k m}^{2}\right)\end{array}$ & $\begin{array}{l}\text { Number } \\
\text { of fires } \\
\left(\text { ave. } \mathbf{y r}^{-1 /}\right. \\
\left.1000 \mathbf{k m}^{2}\right)\end{array}$ & $\begin{array}{c}\text { Fraction of } \\
\text { zone burned } \\
\left.\text { (ave. } \mathrm{yr}^{-1}\right)\end{array}$ & $\begin{array}{c}\text { S.D. of } \\
\text { frac. of } \\
\text { zone } \\
\text { burned }\end{array}$ \\
\hline \multirow[t]{3}{*}{ NW } & Intensive & 82,913 & 5.13 & 0.00584 & 0.00884 \\
\hline & Measured & 30,900 & 2.18 & 0.00563 & 0.01372 \\
\hline & Extensive & 90,121 & 0.60 & 0.01150 & 0.01136 \\
\hline \multirow[t]{2}{*}{$\mathrm{NC}$} & Intensive & $109,599^{1}$ & 2.57 & 0.00152 & 0.00413 \\
\hline & Extensive & 80,290 & 0.21 & 0.00365 & 0.00573 \\
\hline \multirow[t]{3}{*}{ NO } & Intensive & 65,702 & 1.76 & 0.00044 & 0.00049 \\
\hline & Measured & 46,196 & 1.15 & 0.00038 & 0.00573 \\
\hline & Extensive & 143,337 & 0.08 & 0.00310 & 0.00055 \\
\hline NE & Intensive & 79,735 & 5.22 & 0.00029 & 0.00046 \\
\hline $\mathrm{AL}$ & Intensive & 39,307 & 7.22 & 0.00010 & 0.00007 \\
\hline EA & Intensive & 8,677 & 9.95 & 0.00018 & 0.00007 \\
\hline $\mathrm{CE}$ & Intensive & 1,637 & 13.77 & 0.00015 & 0.00014 \\
\hline SW & Intensive & 2,018 & 6.59 & 0.00005 & 0.00005 \\
\hline \multirow[t]{3}{*}{ All } & Intensive & 390,502 & 4.21 & 0.00181 & 0.00285 \\
\hline & Measured & 77,096 & 1.56 & 0.00248 & 0.00551 \\
\hline & Extensive & 313,748 & 0.26 & 0.00438 & 0.00438 \\
\hline
\end{tabular}

${ }^{1}$ This figure includes both intensive and measured protection land (see footnote 2). than 0.005 , fire does not have a significant detrimental impact on timber supply in the boreal forest region of Ontario. That "rule of thumb" coupled with results presented earlier (Table 2) suggest that the effectiveness of Ontario's forest fire management system is such that only Kenora, Red Lake, and Ignace districts may have had their timber supply significantly diminished by fire during the $1976-88$ period. However, since this finding is based on several simplifying assumptions concerning the structure of the forest, industrial capacity, and utilization of timber supply in each district, it is not conclusive. A detailed assessment of the impact of fire on timber supply within a particular district should be based on comprehensive information concerning the structure of the forest, harvest and regeneration practices and costs, and industrial capacity and demand for wood.

As the standard deviations of the fractions of the intensive protection zone burned suggest, the burned area within each district varies significantly from year to year and is illustrated (Figure2) by how the fraction of Kenora District's intensive protection zone burned varied over the 1976-88 fire seasons.

\section{Fire and Timber Supply Models}

Some single stand models can be used to determine the optimal

\begin{tabular}{|c|c|c|c|c|c|}
\hline District & Region & $\begin{array}{c}\text { Intensive protection } \\
\text { zone size } \\
\left(\mathbf{k m}^{\mathbf{2}}\right)\end{array}$ & $\begin{array}{c}\text { Number of fires } \\
\left(\text { ave. } \mathrm{yr}^{-1} / 1000 \mathrm{~km}^{2}\right)\end{array}$ & $\begin{array}{c}\text { Fraction of } \\
\text { intensive protection } \\
\text { zone burned } \\
\left(\text { ave. } \mathrm{yr}^{-1}\right)\end{array}$ & $\begin{array}{c}\text { SD of } \\
\text { fraction of } \\
\text { intensive protection } \\
\text { zone burned } \\
\end{array}$ \\
\hline Kenora & NW & 13,916 & 10.24 & 0.01458 & 0.02763 \\
\hline Red Lake & NW & 15,848 & 3.85 & 0.00842 & 0.01242 \\
\hline Ignace & NW & 11,463 & 3.34 & 0.00829 & 0.01882 \\
\hline Thunder Bay & $\mathrm{NC}$ & $28,451^{1}$ & 3.93 & 0.00467 & 0.01367 \\
\hline Fort Frances & NW & 10,847 & 5.45 & 0.00268 & 0.00438 \\
\hline Temagami & $\mathrm{NE}$ & 6,856 & 4.96 & 0.00151 & 0.00434 \\
\hline Sioux Lookout & NW & 22,894 & 2.61 & 0.00077 & 0.00171 \\
\hline Chapleau & NO & 23,602 & 1.94 & 0.00076 & 0.00114 \\
\hline Atikokan & $\mathrm{NC}$ & $11,321^{1}$ & 4.57 & 0.00065 & 0.00175 \\
\hline Geraldton & NC & $31,580^{1}$ & 1.25 & 0.00059 & 0.00144 \\
\hline Kirkland Lake & NO & 10,650 & 2.02 & 0.00059 & 0.00114 \\
\hline Sudbury & $\mathrm{NE}$ & 12,725 & 13.14 & 0.00054 & 0.00129 \\
\hline Dryden & NW & 11,961 & 5.38 & 0.00050 & 0.00090 \\
\hline Gogama & NO & 7,752 & 2.97 & 0.00029 & 0.00036 \\
\hline Nipigon & $\mathrm{NC}$ & $25,574^{1}$ & 2.11 & 0.00028 & 0.00066 \\
\hline Tweed & EA & 6,605 & 10.34 & 0.00021 & 0.00008 \\
\hline Cochrane & NO & 173 & 4.45 & 0.00020 & 0.00036 \\
\hline North Bay & $\mathrm{NE}$ & 10,668 & 6.11 & 0.00019 & 0.00023 \\
\hline Lindsay & $\mathrm{CE}$ & 1,020 & 12.44 & 0.00016 & 0.00019 \\
\hline Pembroke & $\mathrm{NE}$ & 7,306 & 9.98 & 0.00016 & 0.00016 \\
\hline Hearst & NO & 9,088 & 0.74 & 0.00015 & 0.00023 \\
\hline Carleton Place & EA & 1,674 & 10.75 & 0.00013 & 0.00009 \\
\hline Huronia & $\mathrm{CE}$ & 617 & 15.96 & 0.00013 & 0.00015 \\
\hline Mindon & $\mathrm{AL}$ & 4,745 & 7.96 & 0.00012 & 0.00012 \\
\hline Algonquin Park & $\mathrm{AL}$ & 9,376 & 4.73 & 0.00011 & 0.00018 \\
\hline Wawa & NE & 22,535 & 2.29 & 0.00010 & 0.00015 \\
\hline Bancroft & AL & 4,239 & 6.77 & 0.00008 & 0.00005 \\
\hline Blind River & $\mathrm{NE}$ & 9,516 & 4.10 & 0.00008 & 0.00012 \\
\hline Terrace Bay & $\mathrm{NC}$ & $12,673^{1}$ & 1.94 & 0.00008 & 0.00007 \\
\hline Timmins & NO & 7,645 & 1.93 & 0.00008 & 0.00010 \\
\hline Sault Ste. Marie & $\mathrm{NE}$ & 7,912 & 4.03 & 0.00007 & 0.00010 \\
\hline Espanola & NE & 9,523 & 2.85 & 0.00006 & 0.00014 \\
\hline Parry Sound & $\mathrm{AL}$ & 7,187 & 8.32 & 0.00006 & 0.00003 \\
\hline Owen Sound & SW & 2,018 & 6.59 & 0.00005 & 0.00005 \\
\hline Bracebridge & $\mathrm{AL}$ & 6,454 & 6.25 & 0.00004 & 0.00003 \\
\hline Kapuskasing & $\mathrm{NO}$ & 6,792 & 0.45 & 0.00004 & 0.00001 \\
\hline Napanee & EA & 398 & 0 & 0 & - \\
\hline
\end{tabular}

${ }^{1}$ The North Central region figures are for intensive and measured protection zones combined (see footnote 2). 


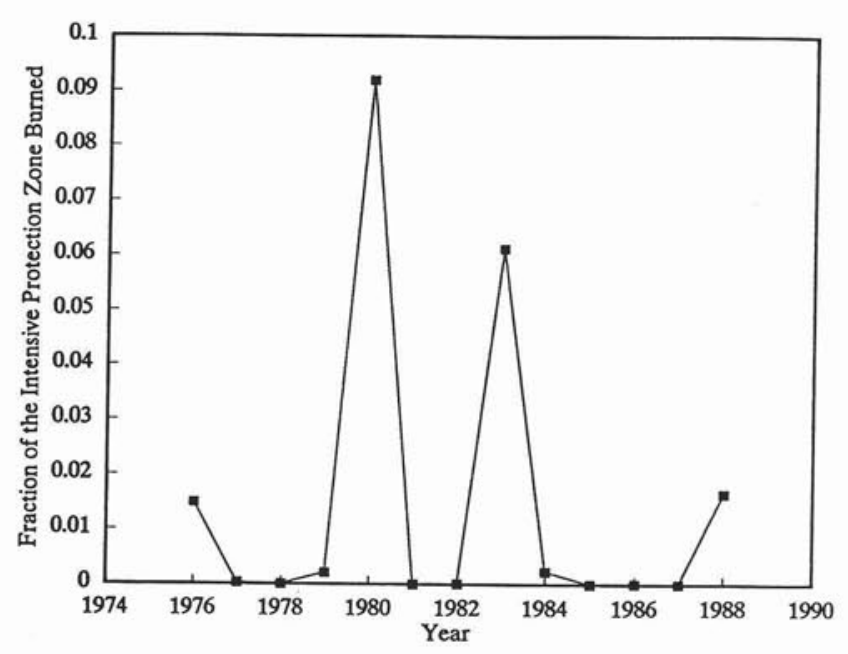

Figure 2. Burned area in Kenora district, 1976-88.

rotation or age at which single stands should be harvested. Martell (1980) used a stochastic regeneration model to determine the optimum rotation of stands that are threatened by fire. He found the optimum rotation decreased as the threat of fire increased, and used his model to estimate the value of fire protection at the stand level. Single stand model results are applicable to small landowners, but they do not adequately address market and industrial capacity considerations (e.g., harvest flow constraints and the ability to substitute young "economically immature" stands for burned stands) that are important to managers of large forests. When single stand models are applied to large forests, they prescribe the immediate cutting of all stands older than their rotation age, and the cutting of younger stands as soon as they reach their rotation age. That can produce very large variations in annual harvest volumes that are not compatible with market demands and industrial capacities, particularly in forests that do not have balanced age class structures.

Van Wagner (1979) developed a simple deterministic simulation model of a fully regulated hypothetical forest and used it to assess the impact of single fires at the start of a planning horizon. This demonstrated clearly the need to assess fire impacts from a forest-wide perspective and showed how fire impact decreased as the age of the burned stand decreased.

Van Wagner (1983) simulated the impact of annual fire losses on a hypothetical black spruce (Picea mariana (Mill.) B.S.P.) forest. The size of the area burned each year was constant but the actual stands that burned were selected at random. He used area control and showed the annual allowable cut volume (AAC) or maximum sustained yield, was a non-linear decreasing function of the fraction of the forest burned each year. An annual fire rate of $1.5 \%$ reduced the AAC by roughly $38 \%$ in his hypothetical forest.

Reed and Errico (1986) developed what they describe in Reed and Errico (1989) as a dynamic equation formulation of the basic Model II harvest scheduling model (Johnson and Scheurman 1977) to explicitly account for probabilistic fire losses. They divided their finite planning horizon into a number of periods and defined a set of state variables that indicate the area in each age class at the start of each time period. Their decision variables are the areas harvested from each age class during each period. Their constraints include dynamic equations which describe how the age class structure of the forest changes from period to period. That enabled them to assume some random proportion of the unharvested area in each age class will burn during each period. Since the resulting stochastic problem is difficult to solve (see the discussion of Gassmann's (1989) work below), they solved the corresponding mean value problem (which they refer to as the "certainty equivalent") obtained by replacing the probabilistic proportion or fraction of the forest burned by its expected value. They suggested that the mean value model be applied iteratively over a finite rolling planning horizon i.e. implement the mean value solution for the first period, cut and observe what actually burns during the first period, solve the revised problem for the new state of the forest, apply the new first period solution to period 2 , and continue using this adaptive feedback scheme for future periods. They argued that for sufficiently large forests, the feedback solution will provide a good approximation to the exact stochastic problem.

Reed and Errico (1986) applied their model to a hypothetical 115,000 ha that was covered by white spruce (Picea glau$c a$ (Moench) Voss) forest which they assumed was reasonably representative of a forested area in northeastern British Columbia. They divided their 720 year planning horizon into thirty six 20-year time periods and imposed harvest flow constraints that limited each period's harvest to within $\pm 10 \%$ of the volume harvested during the previous period. They simulated one 400 year scenario and showed how their model would have performed in that scenario if it had been used to replan every 20 years with a rolling planning horizon. Reed and Errico (1987) subsequently extended their model to account for both average annual fire losses and periodic pest epidemics.

Boychuk (1988) extended Reed and Errico's (1986) model by including decision variables that enable forest managers to include decisions concerning spraying to protect trees against insect defoliation, and he modelled multiple probabilistic outcomes that can result from insect attack, protection, and forest regeneration activities. Reed and Errico's (1986) dynamic model with or without expected fire losses is sufficiently different from the standard version of Model $\mathrm{II}^{4}$ that Boychuk ${ }^{5}$ refers to it as Model III. Similar formulations were also independently developed by Garcia (1984) and Gunn and Rai (1987). Both Garcia $(1984)^{6}$ and Gunn and Rai (1987) explicitly modelled their forests as networks. Garcia's linear programming (LP) formulation was an extension of the network representation he used in his simulation model (Garcia 1981). Boychuk (1988) adapted their network modelling procedures to describe his model and thereby exploited four of the most appealing features of Reed and Errico's (1986) Model III: the ease of expressing forest dynamics in mathematical terms, the ease of representing proportional losses and multiple (proportional) outcomes of activities, the ease of explaining the model to users and others, and the fact that the forest state variables make it easy to describe the age class structures that result from implementing the optimal solution.

\footnotetext{
${ }^{4}$ Reed and Errico (1989) show that the deterministic version of their dynamic model is mathematically equivalent to Model II. Johnson et al. (1986) demonstrate how one can address probabilistic losses by including average fractions of age classes lost in Model II in a manner similar to that used when Reed and Errico solve the mean value version of their problem.

${ }^{5}$ D. Boychuk, Faculty of Forestry, University of Toronto, Personal Communication.

${ }^{6} \mathrm{Garcia}$ (1990) refers to Models I, II, and III as Models C, B and A, respectively.
} 
Gassmann (1989) formulated a smaller version of Reed and Errico's (1986) model with a 140 year planning horizon, as a stochastic programming problem. A linear penalty function helped reduce variability in timber harvest flows over time. He used a stochastic programming algorithm to solve upper and lower bound problems that result from the procedures he used to discretize the continuous distribution of the proportion of the forest burned during each period. He found the first period harvest that resulted from the stochastic programming model solution can differ substantially from the harvest prescribed by the mean value problem, but the difference depends upon the magnitude of the penalty associated with violation of the harvest flow constraints.

Moll (1991) used some features of Boychuk's (1988) model to enhance Reed and Errico's (1987) fire and pest model with pest protection and stand conversion decisions. He did not model multiple outcomes from insect attack, protection, and regeneration activities, and limited himself to a 200 -year planning horizon with 20 -year periods. He explored the validity of the feedback solution approach by randomly generating eight scenarios and demonstrating how the model would have performed had it been used for replanning every 20 years for 200 years. The volumes harvested under all eight scenarios were quite close to those predicted by the mean value problem for the first six periods, but they began to diverge during periods 7 through 10. Unlike Reed and Errico (1986), Moll (1991) ensured that when he replanned at 20 year intervals, the deviation between the new "first" period harvest and the harvest that actually took place during the previous simulated period, did not violate the harvest flow constraints that were imposed on the solution to the original mean value problem.

\section{Fire and Forest Management Planning in Ontario}

Most of the productive forest land in the fire-prone regions of Ontario falls within Crown management units, company management units, and forest management agreement (FMA) forests. Ontario's timber management planning procedures (OMNR 1986a) stipulate that a timber management plan with a 20 year planning horizon be developed for each management unit every 5 years. Those plans describe in considerable detail the forest operations that will be conducted during the first 5 years of the planning horizon. Tworzyanski (1987) describes the planning process which includes the calculation of the Maximum Allowable Depletion (MAD), which is the total area from which timber can be depleted during the first 5 years of the plan by any means including harvesting, fires, insects, and disease. The MAD calculation procedure is essentially an allowable cut technique based on area control forest regulation procedures which allows for the accelerated harvesting of "overmature" forests (e.g., forests in which the average stand age is older than that of a fully regulated "normal" forest). OMNR foresters can avail themselves of a variety of computer-based modelling systems to complete their MAD calculations, including microcomputer spreadsheet software and modified versions of Wang et al.'s (1987) FORMAN simulation model which is based on Hall's (1978) WOSFOP inventory projection model.

Forest managers in Ontario must deal with considerable uncertainty when they develop their timber management plans. Some of the uncertainty results from natural processes such as fire, insects, disease, and weather. They also face uncertainty that results from unforseen land withdrawals (e.g. new parks), changes in technology and markets, and changes in government policy. Potential fire, insect, disease, and weather losses are assumed to take up some unspecified portion of the MAD figure. However, potential loss estimates are not, as they should be, incorporated into the MAD calculation procedure, and there are no formal procedures to suggest how much of the MAD figure should actually be harvested and how much should be left to other depletions.

Forest managers in Ontario account for fire by updating their forest inventory to reflect changes caused by fire and other processes, and replanning at 5 year intervals. They may replan before the scheduled 5 years elapse should a large fire burn a significant portion of their management unit. They also lay out a one year contingency area for cutting during the first 5 years of their plan, to increase the likelihood they will be able to quickly adapt should fire or some other unforseen event consume significant portions of the timber they planned to cut during those 5 years.

Given this planning framework, it is difficult to assess the impact of fire on timber supply in Ontario as a whole. The impact of a fire or a fire management regime will be determined by many factors, including the species, site, and age class distribution of the forest concerned, and the land management objectives and associated plans that are developed and implemented in efforts to attain those objectives. Fire impact assessments must be conducted at the forest management unit or regional level, and the precise results will not be directly transferable from one forest to another. Our objectives were to develop and demonstrate fire impact assessment procedures, and to generate some basic insights into the impact of fire on timber supply in Ontario. We therefore developed mathematical models of simple hypothetical forests and used them to explore what would happen if fire burned portions of those forests, and used those results to generate insight into the impact of fire on the more complex real forests of Ontario. The models and procedures could readily be combined with actual forest management data and used to assess the impact of fire on specific forests.

\section{The hypothetical flammable forest}

Our hypothetical forest management unit was 100,000 ha in size and contained only site class 2 jack pine (Pinus banksiana Lamb.). Two different versions of the forest were considered, that varied only with respect to stand age class distribution. All stands in Forest I were 70 years old at the start of the planning horizon. The stands in Forest II were distributed uniformly within eight 10 -year age classes (i.e., there were 12,500 ha of newly regenerated stands, 12,500 ha of 10 year old stands, $\ldots$ and 12,500 ha of 70 year old stands) at the start of the planning horizon.

A slightly modified version of Reed and Errico's (1986) Model $\mathrm{III}^{7}$ was used to identify and evaluate harvest schedules for our hypothetical forest management unit. The objective was to maximize the expected present net worth over a 300 year planning horizon that was partitioned into thirty 10 -year periods. The entire

\footnotetext{
${ }^{7}$ They allowed harvest volume to increase or decrease by $10 \%$ per period and we constrained our harvest flow to remain constant throughout the planning horizon. They imposed no terminal inventory constraint and we imposed a lower bound on the gross merchantable volume at the end of the planning horizon.
} 
forest management unit was assumed to be fully accessed by roads at the start of the planning horizon and timber harvest schedules were restricted to produce the same volume of wood during each of the 30 time periods. Both harvested and burned areas were assumed to regenerate naturally at no cost with a 5 year delay. All harvests are assumed to occur at the mid-point of each time period and Plonski's (1974) yield table for site class 2 jack pine was used to determine gross merchantable volumes. It was assumed that all harvested wood would be sold for $\$ 30.00 / \mathrm{m}^{3}$ and a $3 \%$ interest rate was used to discount future revenues. Salvage, and the costs of harvesting, transportation, and regeneration activities were ignored.

Simple timber harvest scheduling models with monetary criteria that are optimized over finite planning horizons usually lead to liquidation of the forest at the end of the planning horizon. This possibility was eliminated by considering only timber harvest schedules that leave the forest in a reasonably well stocked state at the end of the planning horizon. It was arbitrarily assumed that the forest management unit must be left stocked with a total of at least 4.02 million $\mathrm{m}^{3}$ of wood $(40.2$ $\mathrm{m}^{3} \mathrm{ha}^{-1}$ ) at the end of the planning horizon. That figure is the gross merchantable volume the 100,000 ha management unit would contain if it were fully regulated with a rotation of 50 years. That terminal constraint makes it possible to reduce Forest II's volume from 8.9 million $\mathrm{m}^{3}$ at the start of the planning horizon, to 4.02 million $\mathrm{m}^{3}$ at the end of the planning horizon, a reduction of 4.88 million $\mathrm{m}^{3}$ or $54.8 \%$. The terminal constraint is quite arbitrary and does not significantly influence the basic form of the results presented in this paper. It was assumed that fire consumed some fixed proportion of the unharvested area in each age class, and that proportion did not vary by time period or age class. Given these modelling assumptions, our mean value model can be expressed as follows.

$x_{\mathrm{i}, \mathrm{t}} \quad=$ Area of age class $i$ at the start of period $\mathrm{t}(\mathrm{ha})$.

$h_{\mathrm{i}, \mathrm{t}} \quad=$ Area of age class $i$ harvested during time period $t$. All harvests occur at the mid-point of the time period (ha).

$r \quad=$ Interest rate used to discount future revenues (\%).

$\alpha \quad=$ Discount factor.

$=1 /(1+r / 100)$.

$S \quad=$ Stumpage rate $\left(\$ / \mathrm{m}^{3}\right)$.

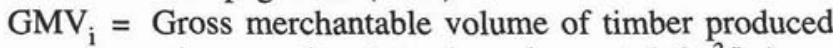
when age class $i$ stands are harvested $\left(\mathrm{m}^{3} / \mathrm{ha}\right)$.

BPP = Fraction of each age class burned during each period. It can vary by age class and time period but we assumed it to be constant.

$\mathrm{A}_{\mathrm{i}} \quad=$ Initial area of age class $i$ at the start of time period 1 (ha).

In order to limit the number of age classes in the model we let the oldest age class be the upper collecting age class. Stands neither grow nor decline in volume once they enter this age class, but they can leave it by being harvested or by burning. Age class 11 (100 years or older) is our upper collecting age class.

Age class 1 ( $0-10$ years old) is our regeneration age class. All harvested and burned stands begin in age class 1 at the start of the next time period. We therefore implicitly assume there is a 5 year delay associated with the regeneration of harvested or burned stands.

\section{Objective function}

Maximize the present net worth of timber sales over the 300 year planning horizon, assuming harvests occur at the mid-point of each 10 year period.

$\max \sum_{i=1}^{30} S \alpha^{(10 \mathrm{t}-5)} \sum_{i=1}^{11} \mathrm{GMV}_{\mathrm{i}} h_{\mathrm{i}, \mathrm{t}}$

Initial age class distribution of the forest

$x_{\mathrm{i}, 1}=A_{\mathrm{i}} \quad i=1, \ldots, 11$

Harvest no more than the available area

$h_{\mathrm{i}, \mathrm{t}} \leq x_{\mathrm{i}, \mathrm{t}} \quad i=1, \ldots, 11 ; t=1, \ldots, 30$

Conservation of area flow into the upper collecting age class

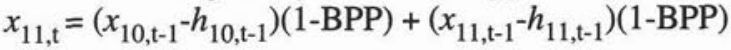

$t=2, \ldots, 31$

Conservation of area flow into the regeneration age class

$x_{1, \mathrm{t}}=\sum_{i=1}^{11} h_{\mathrm{i}, \mathrm{t}-1}+\left(x_{\mathrm{i}, \mathrm{t}-1}-h_{\mathrm{i}, \mathrm{t}-1}\right)(\mathrm{BPP}) \quad t=2, \ldots, 31$

Conservation of area flow into the intermediate age classes

$x_{\mathrm{i}, \mathrm{t}}=\left(x_{\mathrm{i}-1, \mathrm{t}-1}-h_{\mathrm{i}-1, \mathrm{t}-1}\right)(1-\mathrm{BPP}) \quad i=1, \ldots, 10 ; t=2, \ldots, 31$

Constant harvest volume flow

$\sum_{i=1}^{11} \mathrm{GMV}_{\mathrm{i}} h_{\mathrm{i}, \mathrm{t}}=\sum_{i=1}^{11} \mathrm{GMV}_{\mathrm{i}} h_{\mathrm{i}, \mathrm{t}-1} \quad t=2, \ldots, 30$

Terminal volume growing in the forest at the end of the planning horizon

$$
\sum_{i=1}^{\Perp} \operatorname{GMV}_{\mathrm{i}} x_{\mathrm{i}, 31} \geq 4,020,000
$$

We implemented our model using the General Algebraic Modeling System (GAMS) which is described by Brooke $e t$ al. (1988). GAMS is a modelling language that enables one to describe large mathematical programming problems in compact formats using terms that can be easily understood by people, and interpreted by computers. The GAMS computer input is similar to the standard algebraic notation that is commonly used to describe such models and is therefore easily understood by modellers. The model has 702 decision variables and 732 constraints, with 2389 non-zero entries in the matrix. GAMS produced optimal solutions in approximately $11 \mathrm{sec}-$ onds on an IBM 4381-R03 mainframe computer and $30 \mathrm{sec}-$ onds on a Sun SPARCstation 1 workstation.

\section{The Impact of a Fire Regime}

Forest fire managers and their clients who seek to quantify the potential long-term impact of fire on forest ecosystems must look beyond individual fires and consider fire from a macroscopic perspective that focuses on fire regimes. Fire regimes can be characterized by many variables including the number, size, and intensity of fires, and the variation of those parameters over time and space. The characteristics of a fire regime will be determined by many factors including weather, the behaviour of people who may ignite fires, the state of the forest vegetation which is influenced by past fires and land use activities, and the fire management program. We assumed all fires were sufficiently intense to destroy all the timber within their boundaries. 
We restricted our analysis of the impact of fire regimes to simple regimes that differ only in terms of the fraction of the forest consumed by fire each year. We sometimes refer to that burn fraction as the annual burn probability and assumed it does not vary over the planning horizon, nor does it vary from age class to age class. Although these assumptions are somewhat limiting, they facilitate the use of Reed and Errico's (1986) mean value model to assess the impact of fire on timber supply in Ontario $^{8}$.

We began with a simple comparison of two fire regimes, one of which had no fire and another under which an average of $1.5 \%$ of the forest is consumed by fire each year (i.e., an annual burn probability of 0.015 ). If the annual burn probability is $p$ and we use 10 year time periods, the burn probability per period (BPP) is given by equation [9].

$\mathrm{BPP}=1-(1-\mathrm{p})^{10}$

The value of the no-fire regime is assessed by running the GAMS model with an average of $0.0 \%$ of the area of forest burned each year. The second regime is assessed by running the GAMS model with an average annual loss of $1.5 \%$ each year. The two regimes are compared (Table 3 ) as to present net worths and harvest flows that can be produced under each regime for both Forests I and II. The impact of fire on the present net worth and allowable cut does not vary significantly with the initial age class structure of reasonably well endowed forests.

A burn rate of $1.5 \%$ of the forest each year reduces the allowable cut by approximately $35 \%$ in both forests (Table 3 ). Many peoples' intuition suggests that a $1.5 \%$ burn rate should lead to a $1.5 \%$ reduction in harvest levels, and they find it difficult to understand why the harvest reduction is so much greater than the burn rate. However, careful consideration of the potential impact of fire does suggest harvest rate reductions should be much greater than burn rates. The optimal LP harvest schedule for Forest II in the absence of fire prescribes most of the cutting that takes place during periods $18-28$ will be conducted in 55-year-old age class 6 stands. If a small forest stand is picked at random, its annual burn probability will be 0.015 . The probability that it will burn before it is scheduled to be harvested at age 55 would be $1-(1-0.015)^{55}$ or 0.56 , which superficially suggests the harvest might be reduced by as much as $56 \%$. However, burned stands will regenerate and will be stocked with some timber, albeit younger than the planned rotation age, that could be harvested at the planned 55 year rotation. More importantly, since harvest flow is regulated at the forest level, unburned stands can be substituted for burned stands and cut earlier (when they will yield lower volumes per unit area) than they would have been cut in the absence of fire. The actual timber loss will therefore be less than $56 \%$.

The results presented can be expanded to consider the impact of a broad range of annual burn rates on hypothetical Forest II, which, at the start of the planning horizon, is covered with site class 2 jack pine balanced over age classes 1 through 8 . The volume cut each period varies as the annual burn fraction increases from 0.0 to 0.04 when harvest volume is constrained

\footnotetext{
${ }^{8}$ Both Reed and Errico's (1986) model and our version of it can readily accommodate burn fractions that vary by stand age and over time. However, there are currently no age dependant burn fractions available for Ontario's boreal forest species.
}

Table 3. The impact of two fire regimes on 100,000 ha site class 2 jack pine forests, expressed in terms of the present net economic worth of the timber harvested over a $\mathbf{3 0 0}$ year planning horizon, and the volume of wood produced during each 10 year period. Forest $I$ has all stands 70 years old at the start of year 1 and Forest II has its stands uniformly distributed over eight 10-year age classes at the start of year 1.

\begin{tabular}{lcccc}
\hline Forest & $\begin{array}{c}\text { Annual } \\
\text { fraction } \\
\text { burned }\end{array}$ & $\begin{array}{c}\text { Present } \\
\text { net worth } \\
\text { (\$) }\end{array}$ & $\begin{array}{c}\text { Area cut } \\
\text { in Period 1 } \\
\text { (ha) }\end{array}$ & $\begin{array}{c}\text { Volume produced } \\
\text { in Period 1 } \\
\left(\mathbf{m}^{\mathbf{3}}\right)\end{array}$ \\
\hline I & 0.000 & $261,898,384$ & 13,633 & $2,590,237$ \\
& 0.015 & $167,754,139$ & 8,732 & $1,659,128$ \\
\cline { 2 - 5 } & Loss & $35.9 \%$ & & $35.9 \%$ \\
\cline { 2 - 5 } II & 0.000 & $258,561,071$ & 13,547 & $2,557,230$ \\
& 0.015 & $167,350,797$ & 8,711 & $1,655,139$ \\
\hline & Loss & $35.3 \%$ & & $35.3 \%$ \\
\hline
\end{tabular}

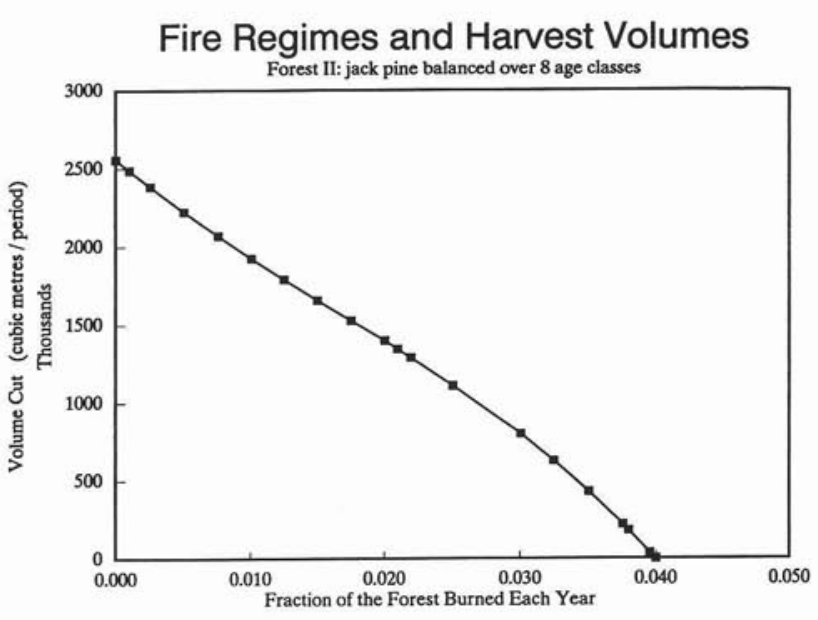

Figure 3. Cut vs. annual burn fraction for Forest II.

to be constant over time (Figure 3). When the fraction burned each year is less then 0.005 the volume cut each period is reduced by less than $15 \%$. Note there are no feasible solutions when the annual fraction burned exceeds 0.04 as the terminal constraint that the forest must be stocked with an average of $40.2 \mathrm{~m}^{3} \mathrm{ha}^{-1}$ cannot be satisfied even if there is no harvesting from the forest under those burning conditions. The first half of the curve, which is convex upwards, is very similar to the annual allowable cut versus percent of the forest burned graph presented by Van Wagner (1983). Our curve becomes concave for large values of the annual burn fraction, a consequence of the constraint on the merchantable volume growing in the forest at the end of the planning horizon. Our finding that an annual burn rate of $1.5 \%$ results in a $35 \%$ reduction in the volume of the harvest from Forest II (Table 3) is comparable with Van Wagner's (1983) finding that a $1.5 \%$ annual burn results in a roughly $38 \%$ reduction in the volume of the harvest from a hypothetical black spruce forest.

\section{The Value of Fire Management}

Assessments of the impact of alternative fire regimes like those described above can be used to assess the value of fire management in terms of the value of timber saved from destruction by fire. One of the consequences of a good fire management program is a reduction of the burn rate from an uncontrolled rate to a lower managed burn rate. The impact of fire management 
is the difference between the value of the timber that can be harvested from a forest that benefits from fire management, and the value of the timber that can be produced from a forest that is subjected to an unmanaged fire regime. The value of fire management is therefore the timber value with the "managed" burn rate less the timber value with an uncontrolled natural fire regime burn rate.

Little is known about Ontario's natural fire regime and the degree to which it varied across the province, and even less is known about the extent to which fires that did burn were lethal. Woods and Day (1977) suggested the fire cycle (the average time between fires on a sample point selected at random) in Quetico Provincial Park, which lies within the Great LakesSt. Lawrence Forest Region (Rowe 1972), was 78 years before fire suppression was initiated there in 1920. Reported natural fire intervals for different parts of Ontario span a broad range including 37 years (Burgess and Methven 1977) and 30 years (Alexander et al. 1979). Given current land use patterns, it is probably reasonable to assume a fire cycle of less than 50 years or an annual burn fraction of 0.02 or more in the absence of fire management. Suppose a fire management program reduces the annual burn fraction in Forest II from 0.020 (no fire management) to 0.001 (Level 1). The results indicate (Table 4) the fire management program would produce savings over a 300 year planning horizon with a present net worth of $\$ 110$ million. This represents a saving of $\$ 1100 \mathrm{ha}^{-1}$, which can be transformed into an equivalent annual saving of approximately $\$ 32 \mathrm{ha}^{-1} \mathrm{yr}^{-1}$. If the fire management program costs less than $\$ 32 \mathrm{ha}^{-1} \mathrm{yr}^{-1}$, it more than pays for itself. ${ }^{9}$

Suppose fire management only reduced the annual burn fraction to 0.00183 (Level 2), close to the 1976-88 average of 0.0019 for intensive and measured protection zone land in Ontario. The results indicate (Table 4) the net savings from fire management in our hypothetical Forest II would be approximately \$105 million over a 300 year planning horizon. That would represent a saving of $\$ 1047$ per ha which can be transformed into an equivalent annual saving of $\$ 30.50 \mathrm{ha}^{-1} \mathrm{yr}^{-1}$.

The fixed cost of the OMNR's basic forest fire management program is roughly $\$ 48.4$ million $\mathrm{yr}^{-1}$, and Extra Fire Fighting costs average approximately $\$ 34.3$ million $\mathrm{yr}^{10}$. If we assume that $\$ 82.7$ million is spent on the $46,759,800$ ha of the intensive and measured protection zones, it represents a cost of $\$ 1.77$ $\mathrm{ha}^{-1} \mathrm{yr}^{-1}$. Given this information, one can extrapolate the results for our hypothetical Forest II to the entire province to produce a very rough estimate of the value of Ontario's fire management program.

The area of the province of Ontario is $1,068,000 \mathrm{~km}^{2}$, but the OMNR's forest resources inventory covers a portion of the province that has an area of only $616,000 \mathrm{~km}^{2}$. If the area of lakes, rivers, and land that is not devoted to timber production is subtracted, Ontario's production forest land base is approximately $353,000 \mathrm{~km}^{2}$ or 35.3 million ha (Ontario Ministry of Natural Resources 1986b) in size. The results for our hypothetical Forest II suggest that if all of Ontario's productive forest land

\footnotetext{
${ }^{9}$ It would be necessary to consider marginal costs and returns to fire management in order to identify the optimum level of fire management. We would need to specify the relationship between annual burn fraction and fire management expenditures in order to identify an optimal solution.

${ }^{10}$ P.C. Ward, Aviation Flood, and Fire Management Centre, Ontario Ministry of Natural Resources, Personal Communication.
}

Table 4. The impact of fire management programs that reduce the annual fraction of Forest II from 0.02000 to 0.00100 or 0.00183 . Forest II has its stands uniformly distributed over age classes 1 through 8 at the start of year 1.

\begin{tabular}{|c|c|c|c|c|}
\hline $\begin{array}{l}\text { Fire } \\
\text { management } \\
\text { regime }\end{array}$ & $\begin{array}{l}\text { Annual } \\
\text { fraction } \\
\text { burned }\end{array}$ & $\begin{array}{c}\text { Present } \\
\text { net worth } \\
\text { (\$) }\end{array}$ & $\begin{array}{c}\text { Area cut } \\
\text { in Period } 1 \\
\text { (ha) }\end{array}$ & $\begin{array}{c}\text { Volume produced } \\
\text { in Period } 1 \\
\left(\mathrm{~m}^{3}\right)\end{array}$ \\
\hline None & 0.02000 & $141,350,900$ & 7,358 & $1,397,994$ \\
\hline \multirow[t]{2}{*}{ Level 1} & $\underline{0.00100}$ & $251,570,459$ & 13,150 & $2,488,091$ \\
\hline & Savings & $\begin{array}{c}110,219,559 \\
(78.0 \%)\end{array}$ & & $\begin{array}{c}1,090,097 \\
(78.0 \%)\end{array}$ \\
\hline \multirow[t]{2}{*}{ Level 2} & 0.00183 & $246,019,264$ & 12,834 & $2,433,189$ \\
\hline & Savings & $\begin{array}{c}104,668,364 \\
(74.0 \%)\end{array}$ & & $\begin{array}{c}1,035,195 \\
(74.0 \%)\end{array}$ \\
\hline
\end{tabular}

was similar to it, and was fully managed and exploited for timber, the fire management program would produce a timber saving of $\$ 30.50 \mathrm{ha}^{-1} \mathrm{yr}^{-1}$ or $\$ 1,077$ million dollars $\mathrm{yr}^{-1}$ across the province. However, since the province's forest land is not all like Forest II, nor is it being fully exploited, the $\$ 1,077$ million figure is not a valid estimate of the timber value of forest fire management in Ontario.

The timber saving due to fire management of $\$ 30.50 \mathrm{ha}^{-1}$ $\mathrm{yr}^{-1}$ in our hypothetical Forest II was based on an assumption that the stumpage rate for wood is $\$ 30.00 / \mathrm{m}^{3}$ which is higher than the true stumpage rates for wood in the fire prone areas of Ontario. Suppose the stumpage rate of wood was reduced to a more realistic value of $\$ 7.50 / \mathrm{m}^{3}{ }^{11}$ The timber saving in Forest II would then be reduced to $\$ 7.63 \mathrm{ha}^{-1} \mathrm{yr}^{-1}$.

Let us assume that Ontario's average annual forest fire management budget of $\$ 82.7$ million is devoted to the 35.3 million ha of productive forest land (a rate of approximately $\$ 2.35 \mathrm{ha}^{-1} \mathrm{yr}^{-1}$ ). However, only 20.6 million $\mathrm{m}^{3}$ of hardwood and softwood were harvested from Crown land in Ontario in 1988 (OMNR 1989). That suggests Ontario may be exploiting only $24 \%$ of the 85.8 million $\mathrm{m}^{3}$ harvest that could be taken from a fully exploited version of Forest II that covered all of Ontario's productive forest land. Since not all of Ontario's productive forest land is fully exploited, nor is it all site class II jack pine, we cannot assume the fire management expenditure of $\$ 2.35 \mathrm{ha}^{-1} \mathrm{yr}^{-1}$ would produce a timber "profit" of $\$ 7.63 \mathrm{ha}^{-1}$ of Ontario's productive forest land.

Let us make a gross simplifying assumption that since the volume of wood harvested from crown land in Ontario in 1988 was only $24 \%$ of the volume that could have been harvested from a full Ontario version of Forest II, only $24 \%$ of Ontario's 35.3 million ha of productive forest land or 8.47 million ha is actually being used for timber production, and all that land is covered with site class II jack pine that is being fully exploited. That would produce a very conservative estimate that the $\$ 82.7$ million fire management would produce a timber profit of 8.47 million ha $\times \$ 7.63 \mathrm{ha}^{-1} \mathrm{yr}^{-1}$ or $\$ 64.6$ million $\mathrm{yr}^{-1}$. These conservative estimates, coupled with the fact that fire management also benefits public safety and reduces property loss, suggest that forest fire management is profitable in Ontario ${ }^{12}$.

${ }^{11}$ B. Callaghan, Timber Production Policy Project, Sustainable Forestry
Program, Ontario Ministry of Natural Resources, Personal Communication. 
These results support a belief held by foresters for many years (e.g., Baskerville 1986), namely, that fire protection is one of the most powerful and cost effective tools available to enhance the timber productivity of the boreal forest. Our results show that, if fire management reduces the burn rate in our hypothetical Forest II from $2 \%$ per annum to $0.1 \%$ per annum, the annual volume harvested from that forest could increase from 139,799 $\mathrm{m}^{3}$ to $243,319 \mathrm{~m}^{3} \mathrm{yr}^{-1}$. That represents a $74 \%$ increase in productivity that can be achieved at a relatively small cost.

\section{Discussion}

Our statistical analysis of historical fire data and our assessment of the impact of fire in our hypothetical forests suggest that although fire may have had some detrimental impact on timber supply in some parts of the Northwestern region during the 1976-88 period, the effectiveness of Ontario's forest fire management system is such that timber supply in most districts has not been significantly diminished by fire. Our superficial assessment of Ontario's fire management expenditures and performance and the fact that fire management also benefits public safety and saves property, suggest that forest fire management saves more than it costs in Ontario.

A modified version of Reed and Errico's (1986) mean value problem was used to evaluate selected aspects of the impact of fire on timber supply. Although their model constitutes a very important contribution, the solutions it produces are not necessarily optimal solutions to the stochastic programming problems that fire and forest managers must resolve. The mean value solutions and the fire impact assessments based upon those solutions are simply approximations. Moll (1991) provided some insight into the performance of the mean value approximation procedure with replanning, by exploring how it performed when applied to a small number of simulated scenarios. More thorough investigations are needed of the accuracy of the mean value approximations.

Furthermore forest management planning horizons usually extend over hundreds of years and forest managers will always have to deal with a lot of uncertainty. Although computer technology and the performance of stochastic programming algorithms will improve, forest managers will always have to satisfice ${ }^{13}$ rather than optimize. Replanning with rolling planning horizons is obviously a practical strategy for forest management in the face of uncertainty, but we need to investigate how best

\footnotetext{
${ }^{12}$ The hypothetical net savings attributed to Ontario's forest fire management program is a rough approximation based on very simplifying assumptions. We assumed only $24 \%$ of the province's entire production forest is being fully exploited and that it is all like our hypothetical Forest II. Only $35 \%$ of the 1988 harvest from Crown land was jack pine, while 52\% was spruce (OMNR 1989) and the value of wood (which we assumed was $\$ 7.50 / \mathrm{m}^{3}$ ) and fire losses vary considerably across the province. We have also ignored regeneration costs and future technology, demands, and prices. A detailed examination of fire and forest management practices at the regional or management unit level would provide a much more accurate assessment of the true value of forest fire management in Ontario, but that was beyond the scope of this study.

${ }^{13}$ H.A. Simon (1976) used the term "satisfice" to describe how decision-makers actually behave. He suggested they do not always optimize, but rather, they identify some measure of effectiveness (e.g., area burned) and search for an alternative that will achieve some arbitrary level of that effectiveness measure (e.g., burn no more than $\mathrm{x} \%$ of the forest each year). Their evaluation of alternatives is seldom exhaustive as they often suspend the process once they have found an alternative that satisfies their level of effectiveness goal.
}

to apply that approach. Issues like the encoding of uncertainty, period size, the length of the planning horizon, harvest flow constraint, and terminal conditions are prime candidates for detailed investigations.

Finally, although the focus of this study was the impact of fire on timber supply, one must look beyond timber supply and evaluate the impact of fire on the many other attributes of forests. The relative ease of assessing the timber supply implications of fire must not drive fire management at the expense of other important considerations. Fire is a natural component of many of Canada's forested ecosystems and we are in the midst of significant changes in the way people view and value forests. Mathematical programming models can be adapted to assess the impact of fire and fire management practices on most forest values, and they can be used to help resolve a broad array of forest management decision-making problems.

\section{Acknowledgements}

This research was supported by Forestry Canada and the Ontario Ministry of Natural Resources under the Research, Development and Applications Sub-Program of the Canada-Ontario Forest Resource Development Agreement (1984-1989). GAMS software was used to solve the linear programming models described in this paper. I wish to thank the World Bank for permission to use a copy of mainframe GAMS which was loaned to J.S. Rogers for testing purposes, and A. Meeraus of GAMS Development Corporation, for his helpful advice concerning the use of GAMS. R.G. Davis worked as a research assistant on this project, and provided helpful comments on an earlier version of this paper. I also wish to thank D. Boychuk, F.M. Dunn, A. Tithecott, P.C. Ward, and C.E. Van Wagner for their helpful comments on earlier versions of this paper.

\section{References}

Alexander, M.E., J.A. Mason, and B.J. Stocks. 1979. Two and a half centuries of recorded fire history. Canadian Forestry Service. Great Lakes Forest Research Centre Leaflet. Sault Ste. Marie, Ont. 2 p.

Baskerville, G. 1986. Understanding forest management. Forestry Chronicle 62(4): 339-347.

Boychuk, D. 1988. An LP model to evaluate spruce budworm control alternatives. Paper presented at TIMS/ORSA Joint National Meeting. Washington, D.C. April 25-27, 1988.

Brooke, A., D. Kendrick and A. Meeraus. 1988. GAMS: a user's guide. The Scientific Press. San Francisco, CA.

Burgess, D.M. and I.R. Methven. 1977. The historical interaction of fire, logging, and pine: a case study at Chalk River, Ontario. Canadian Forestry Service Information Report -PS-X-66. Petawawa Forest Experiment Station. Chalk River, Ont. 18 p.

Garcia, 0. 1981. IFS, an interactive forest simulator for long range planning. New Zealand Journal of Forestry Science 11: 8-22.

Garcia, 0. 1984. FOLPI: A forestry-oriented linear programming interpreter. In H. Nagumo et al. (Editors). pp. 293-305. Proceedings of IUFRO Symposium on Forest Management Planning and Managerial Economics. University of Tokyo.

Garcia, O. 1990. Linear programming and related approaches in forest planning. New Zealand Journal of Forestry Science 20(3): $307-$ 31.

Gassmann, H.I. 1989. Optimal harvest of a forest in the presence of uncertainty. Can. J. For. Res. 19(10): 1267-1274.

Gunn, E.A. and A.K. Rai. 1987. Modelling and decomposition for planning long-term forest harvesting in an integrated industry structure. Can. J. For. Res. 17: 1507-1518.

Hall, T.H. 1978. Toward a framework for forest management decision-making in New Brunswick. New Brunswick Department of 
Natural Resources, Fredericton, New Brunswick. New Brunswick Report No. TR1-78.

Johnson, K.N. and H.L. Scheurman. 1977. Techniques for prescribing optimal harvest and investment under different objectives - discussion and synthesis. For. Sci. Monograph 18. 31 p.

Johnson, K.N., T.W. Stuart and S.A. Crim. 1986. FORPLAN Version 2: An Overview. United States Department of Agriculture Forest Service, Land Management Planning Systems Section, Fort Collins, Colorado.

Martell, D.L. 1980. The optimal rotation of a flammable forest stand. Can. J. of For. Res. 10: 30-34.

Moll, R.H.H. 1991. Modelling regeneration and pest control alternatives for a forest system in the presence of fire risk. Ph.D. Thesis. Department of Systems and Computer Engineering. Carleton University. Ottawa, Ontario. 192 p.

Ontario Ministry of Natural Resources. 1982. Forest fire management policy: a statement of policy by the Ministry of Natural Resources governing forest fire control and use in Ontario. Publication \#126, Aviation and Fire Management Centre, Ontario Ministry of Natural Resources. Sault Ste. Marie. 16 p.

Ontario Ministry of Natural Resources. 1986a. Timber management planning manual for Crown lands in Ontario. Toronto: Queen's Printer for Ontario. $x i+218$ p.

Ontario Ministry of Natural Resources. 1986b. The forest resources of Ontario 1986. Forest Resources Group, Ministry of Natural Resources. Toronto. Queen's Printer for Ontario. 91 p.

Ontario Ministry of Natural Resources. 1989. Statistics 1988-

1989. A statistical supplement to the annual report of the Minister of Natural Resources for the year ending March 31, 1989. Queen's Printer for Ontario. Toronto. $117 \mathrm{p}$.

Plonski, W.L. 1974. Normal yield tables (metric) for major forest species of Ontario. Ontario Ministry of Natural Resources, Toronto, Ontario. 40 p.

Reed, W.J. and D. Errico. 1986. Optimal harvest scheduling at the forest level in the presence of the risk of fire. Can. J. For. Res. 16: 266278.

Reed, W.J. and D. Errico. 1987. Techniques for assessing the effects of pest hazards on long-run timber supply. Can. J. For. Res. 17: 1455-1465.

Reed, W.J. and D. Errico. 1989. A new look at whole-forest modelling. Nat. Res. Mod. Vol. 3. No. 3: 399-427.

Rowe, J.S. 1972. Forest regions of Canada. Canadian Forestry Service, Publication No. 1300. Ottawa. 172 p.

Simon, H.A. 1976. Administrative behaviour. Third Edition. The Free Press. New York, N.Y. 364 p.

Tworzyanski, T. 1987. Annual cut versus forest depletion: Ontario's approach to wood supply analysis. Can. For. Ind. 1987(September): 565-569.

Van Wagner, C.E. 1979. The economic impact of individual fires on the whole forest. Forest. Chron. 55(2): 47-50.

Van Wagner, C.E. 1983. Simulating the effect of forest fire on long-term annual timber supply. Can. J. Forest Res. 13: 451- 457.

Wang E., T. Erdle and T. Roussell. 1987. Forman wood supply model - user manual. New Brunswick Executive Forest Research Committee Inc.

Woods, G.T. and R.J. Day. 1977. A summary of the fire ecology study of Quetico Provincial Park. Ontario Ministry of Natural Resources. Report No. 8. Fire Ecology Study. Atikokan District. 39 p. 